DOI 10.15290/cnisk.2017.01.02.06

\author{
DR KAROLINA KUŚMIREK
}

Uniwersytet Marii Curie-Skłodowskiej w Lublinie

\title{
Służba kobiet w siłach zbrojnych
}

\section{Streszczenie}

Służba kobiet w siłach zbrojnych różnych państw wymaga poświęcenia i przezwyciężenia trudności takich jak stereotypowy sposób myślenia czy możliwość awansowania. Przeciwnicy służby kobiet w armii podnosili kwestie różnic między kobietami i mężczyznami w procesie selekcyjnym, np. niższe wymagania fizyczne.

Obecnie kobiety pełnią obowiązki medyków, psychologów lub pracują w innych zawodach, w zależności od państwa. Coraz częściej także stanowiska zarezerwowane wcześniej dla mężczyzn, np. mechanik, obejmują też kobiety.

Kobiety w siłach zbrojnych łączą wspólne wartości, chęć przeżycia przygody i realizacja ich pasji.

Słowa kluczowe: siły zbrojne • służba wojskowa • kobiety

\section{THE SERVICE OF WOMEN IN THE ARMED FORCES}

\section{Abstract}

The service of women in the armed forces of different countries requires dedication and overcoming obstacles resulting from stereotypical ways of thinking which often limit women's access to the highest posts in the Army. Opponents of women's presence in the military rely on the lower female standards in physical performance in recruitment and selection processes. Today, the number of jobs open to women in the armed forces depends on the country. Although women in 
the Army usually serve as doctors and psychologists, more and more of them are moving into once male-dominated jobs. Women in the armed forces share common values and beliefs - a sense of adventure and a desire to follow their passions.

Keywords: the armed forces $\bullet$ military services $\bullet$ women

\section{Wprowadzenie}

W XXI w. służba kobiet w siłach zbrojnych stała się przedmiotem zainteresowania opinii publicznej. Środki masowego przekazu opisywały kryteria, jakie musza spełnić kandydatki, oraz realia służby. Należy zaznaczyć, że wzrost liczby kobiet służących w armii wynikał ze zmian zachodzacych w siłach zbrojnych ${ }^{1}$. Ze względu na zniesienie obowiązkowej służby wojskowej na rzecz armii zawodowej stała się ona nowym rynkiem pracy, gdzie istotnym czynnikiem zatrudnienia były przede wszystkim kwalifikacje poszczególnych osób.

Inna przyczyna, która umożliwiła służbę kobiet, była zmiana stereotypowego myślenia o „słabej” płci, która nie poradzi sobie w siłach zbrojnych. Współczesne wyzwania bezpieczeństwa międzynarodowego wymagaja także zaangażowania kobiet w działania militarne, np. operacje psychologiczne czy realizacje zadań, podczas których dezorientuja one przeciwnika². Niewątpliwie rozwój i użycie nowych technologii oraz zmiany charakteru działań pozwoliły na zwiększenie liczby kobiet w siłach zbrojnych.

\footnotetext{
${ }^{1} \mathrm{Na}$ przestrzeni dziejów wojna i związana $z$ nią służba były przypisywane przede wszystkim mężczyznom. Stanowiły o ich heroizmie i umożliwiały zapewnienie bezpieczeństwa społeczności, z których się wywodzili. Kobiety postrzegane były jako opiekunki domowego ogniska. Ten archetyp został zakorzeniony w świadomości społeczeństwa, dlatego też służba kobiet w armii wciąż jest przedmiotem dyskusji (Ch. Hann, Antropologia społeczna, tłum. S. Szymański, Kraków 2008, s. 138; cf. T.C. Lewellen, Antropologia polityczna, tłum. A. Dabrowska, T. Sieczkowski, Santa Barbara 2003, s. 171; J. Czaja, Kulturowe czynniki bezpieczeństwa, Kraków 2008, s. 208).

2 E.L. Haring, What Women Bring to the Fight, „Parameters” 2013, Vol. 43, No. 2, passim.
} 
Prezentując tematykę kobiet w siłach zbrojnych, należy wskazać na takie zagadnienia, jak trudności, $z$ którymi zmagaja się kobiety w armii, wymagania fizyczne oraz stanowiska, na których służą. Celem niniejszego artykułu jest odpowiedź na pytanie: na czym polega służba kobiet w siłach zbrojnych poszczególnych państw, jak również przedstawienie tych aspektów służby, które definiuja ich miejsce i rolę w tej instytucji.

Wśród publikacji jako szczególnie wartościowe wskazać należy pozycje Mileny Palczewskiej i Barbary Drapikowskiej Służba wojskowa kobiet wyzwaniem dla Sił Zbrojnych $R P$, Wilhelminy Wosińskiej Psychologia życia społecznego czy też Bogdana Wojciszke Człowiek wśród ludzi. Zarys psychologii społecznej.

\section{Uwarunkowania psychospołeczne}

Służba kobiet w siłach zbrojnych wymagała przełamania stereotypowego myślenia, które wyrażało się w podziale zawodów na te zarezerwowane jedynie dla mężczyzn, np. mechanik, oraz te wykonywane wyłacznie przez kobiety, np. pielęgniarka ${ }^{3}$. Kobiety sprawdzaja się na stanowiskach wymagających spostrzegawczości i analitycznego myślenia. Niewątpliwie mężczyźni - ze względu na warunki fizyczne - potrafili wykonywać czynności wymagające większej siły fizycznej, jednak dzisiejsza zaawansowana technologia w większym stopniu umożliwia włączenie kobiet w działania militarne.

Krytycy obecności kobiet w armii prezentowali pogląd, że obniżają one morale żołnierzy czy rozpraszaja uwage mężczyzn podczas wykonywania zadań. Innym czynnikiem, który definiował miejsce kobiet w armii, było spełnienie przez nie wymagań fizycznych podczas procesu rekrutacyjnego.

3 W. Wosińska, Psychologia życia społecznego, Gdańsk 2004, s. 344-345; cf. B. Wojciszke, Człowiek wśród ludzi. Zarys psychologii społecznej, Warszawa 2006, s. 420; B. Hołyst, Bezpieczeństwo gatunku ludzkiego, Warszawa 2016, s. 375 . 
Zróżnicowanie wymogów dotyczących sprawności fizycznej ze względu na płeć zostało odebrane negatywnie, ponieważ łagodniejsze kryteria umożliwiły kobietom łatwiejszy dostęp do służby. Pomimo obniżonych wymagań zróżnicowaniu uległy także stanowiska, na które moga aplikować kobiety. Nie podejmuja służby w zespołach bojowych, lecz sa przydzielane do działań zabezpieczajacych operacje. Barbara Drapikowska poruszyła tę problematykę w artykule Kompetencje dowódcze kobiet - żotnierzy, postulujac stworzenie katalogu stanowisk, do których kobiety posiadają większe predyspozycje niż mężczyźni ${ }^{4}$.

Warto wskazać też na czynnik psychologiczny, czyli mentalność mężczyzn, którzy odruchowo chronili kobietę na polu walki bądź też dzielili między sobą obowiązki związane $z$ noszeniem ciężkich rzeczy. Taka postawa zwiększałaby niepowodzenie operacji lub mogła narazić członka zespołu na niebezpieczeństwo. Zapewne dopasowanie wymagań do stanowiska, bez różnicowania ze względu na płeć, pozwoliłoby na wybranie kandydata prezentującego optymalne cechy psychofizycznej umiejętności do służby.

Inną kwestią są wyzwania (ergonomia, eliminacja molestowania), które stoja przed siłami zbrojnymi poszczególnych państw oraz przed samymi kobietami żołnierzami. W tym zakresie prowadzone sa działania prewencyjne i edukacyjne opisane w Strategii umacniania dyscypliny, przeciwdziałania uzależnieniom oraz zapobiegania patologiom społecznym w Siłach Zbrojnych Rzeczypospolitej Polskiej w latach 2010-20155.

4 B. Drapikowska, Kompetencje dowódcze kobiet - żołnierzy [w:] Zarzadzanie $i$ dowodzenie we wspótczesnych uwarunkowaniach, red. M. Chmielecki, M. El Ghmari, Warszawa 2012, s. 22; vide: R.B. Cialdini, D.T. Kenrick, S.L. Neuberg, Psychologia społeczna, tłum. A. Nowak, Gdańsk 2006, s. 600.

5 Sejm RP, Odpowiedź podsekretarza stanu w Ministerstwie Obrony Narodowej z upoważnienia ministra - na interpelację nr $16633 \mathrm{w}$ sprawie służby zawodowej kobiet w armii [Dostęp: 10.01.2017]. Dostępny w World Wide Web: $<$ http://orka2.sejm.gov.pl>. 
Była Pełnomocnik Ministerstwa Obrony Narodowej ds. wojskowej służby kobiet kmdr Bożena Szubińska ${ }^{6}$ wyraziła opinię, że kobiety służące w wojsku muszą mieć silny charakter, być odporne na trudy służby, a także wykazywać chęć do podnoszenia swoich umiejętności. Przezwyciężenie przekonania, że kobiety nie są zdolne do służby w siłach zbrojnych, wciąż stanowi wyzwanie.

Od poczatku pojawienia się pierwszych kobiet w szeregach Sił Zbrojnych Rzeczypospolitej Polskiej pokonywały one trudności zwiazane $z$ koniecznościa udowodnienia swoim współpracownikom, że podołaja wszelkim trudom. Na przestrzeni lat wiele $z$ tych problemów udało się rozwiązać, nadal też sa podejmowane działania niwelujące ich skutki?

\section{Służba kobiet w Siłach Zbrojnych Rzeczypospolitej Polskiej}

Podejmowanie działań militarnych w siłach zbrojnych przez kobiety nie jest nowa koncepcja. Warto przypomnieć ich udział w wydarzeniach historycznych, np. Emilia Plater uczestniczyła w powstaniu listopadowym, w którym stanęła m.in. na czele oddziału kosynierów. Kobiety aktywnie uczestniczyły w działaniach podczas II wojny światowej, były sanitariuszkami, łacznikami, żołnierzami. Przykładem jest gen. Elżbieta Zawacka, która była jedyna kobieta w szeregach cichociemnych - spadochroniarzy Armii Krajowej8. Innym przykładem jest Maria Stypułkowska-

6 Kmdr Bożena Szubińska była współzałożycielką i przewodniczącą Rady ds. Kobiet w Siłach Zbrojnych Rzeczypospolitej Polskiej, a następnie pełniła funkcje męża zaufania w Zarządzie Wojskowej Służby Zdrowia Sztabu Generalnego Wojska Polskiego (Przewodniczaca Rady ds. Kobiet w SZ RP [Dostęp: 10.01.2017]. Dostępny w World Wide Web: <http:mon.gov.pl/pl>; 25 lat wojskowej służby kobiet, red. B. Szubińska, A. Szczygielska, D. Kurek, Warszawa 2015, passim). 7 JM, Armia celuje $w$ kobiety. Chce mieć ich więcej $w$ swoich szeregach [Dostęp: 10.01.2017]. Dostępny w World Wide Web: <http://www.pulshr.pl>.

8 Elżbieta Zawacka (1909-2009), kurier Komendy Głównej Armii Krajowej, jedyna kobieta wśród cichociemnych. Po wojnie pracowała jako nauczyciel i wykładowca akademicki (Elżbieta Zawacka: byłam jedyna Cichociemna [Dostęp: 10.01.2017]. Dostępny w World Wide Web: http://www.polskieradio.pl); więcej 
-Chojecka, która dała sygnał do rozpoczęcia akcji „Kutschera”9. Kobiety, które walczyły o niepodległa Polskę, wykorzystywały efekt zaskoczenia, w konsekwencji destabilizując działania wroga. Należy zauważyć, że ich zadania były tak samo niebezpieczne jak żołnierzy walczących na froncie. Te przykłady działalności kobiet $\mathrm{w}$ czasie wojny potwierdzaja, że, walcząc $z$ wrogiem, stanowiły ważna część ruchu oporu10. Dziś także udział kobiet w działaniach militarnych jest równie ważny.

W związku $z$ akcesem Rzeczypospolitej Polskiej do NATO zmieniło się podejście do roli kobiet $\mathrm{w}$ polskiej armii. Otwartość państw członkowskich na partycypację kobiet w siłach zbrojnych zmieniła również sytuację w Polsce. W 1999 r. kobiety uzyskały możliwość podjęcia nauki w szkołach wojskowych. Wymagania na egzaminie fizycznym były odmienne dla płci, egzamin $z$ wiedzy teoretycznej był zaś jednakowy. Kolejny ważny etap w dostępie kobiet do służby nastapił w 2007 r. w wyniku zniesienia powszechnej służby wojskowej na rzecz profesjonalizacji sił zbrojnych.

Kobiety stanowią 4,70\% ogółu żołnierzy służących w Siłach Zbrojnych Rzeczypospolitej Polskiej. Biorąc pod uwagę osiagalność stopni wojskowych, największy odsetek kobiet służy w korpusie szeregowych (2823 osób), równie duży w korpusie oficer-

na ten temat: Służba Polek na frontach II wojny światowej. Materiały sesji popularnonaukowej $w$ Toruniu $w$ dniach 16-17 listopada 1996 roku. Cz. 2. Referaty $i$ komunikaty, red. E. Zawacka, Torun 1998, passim).

9 Zamach na Franza Kutschere [Dostęp: 10.01.2017]. Dostępny w World Wide Web: http://www.polskieradio.pl; cf. J. Swalski, Pamięć po latach. Wspomnienia uczestników zamachu na Franza Kutschere [Dostęp: 28.01.2017]. Dostępny w World Wide Web: http://www.polskieradio.pl; MM/PAP, Zabić kata [Dostęp: 28.01.2017]. Dostępny w World Wide Web: <www.newsweek.pl>).

10 Każdy żołnierz sił zbrojnych, bez względu na płeć, narażony jest na stres związany ze służbą. Dążenie do unormowania własnych emocji oraz zmniejszenie ekspozycji na czynnik stresogenny pozwala na efektywniejsze wykonywanie swoich obowiązków (B. Rokicki, Stres [w:] Psychospołeczne uwarunkowania zachowań jednostek i grup spolecznych $w$ sytuacji zagrożen. Wybrane problemy, red. K. Loranty, Warszawa 2010, s. 117; vide: E. Aronson, Człowiek istota społeczna, tłum. J. Radzicki, Warszawa 2009, s. 221). 
skim (1329 osób) ${ }^{11}$. Warto zauważyć, że obecnie nie ma kobiety w stopniu generała. Niski współczynnik płci żeńskiej na wysokich stanowiskach może wynikać $z$ obowiązków rodzinnych (urodzenie i wychowanie dzieci), kiedy to wybierają one głównie pracę administracyjna (np. działania podczas misji zagranicznych), ograniczając tym samym swoje możliwości szybkiego osiagnięcia wyższego stopnia 12 .

Analizując poszczególne rodzaje sił zbrojnych, należy wskazać, że najwięcej kobiet żołnierzy służy w wojskach lądowych (1507 osób), najmniej zaś w wojskach specjalnych (45osób), co wynika ze specyfiki służby oraz wymagającej selekcji. $Z$ kolei w instytucjach najmniej kobiet żołnierzy pracuje w Sztabie Generalnym Wojska Polskiego - tylko dwie osoby, w Ministerstwie Obrony Narodowej natomiast 25 osób. Powyższe dane są dowodem na relatywnie niski współczynnik kobiet, które zajmuja prominentne stanowiska w siłach zbrojnych, tendencja ta jednak dotyczy także mężczyzn. Im wyższa ranga zajmowanego stanowiska, tym trudniej awansować w instytucji ${ }^{13}$.

Charakteryzując rolę kobiet $\mathrm{w}$ wojsku, należy stwierdzić, że zazwyczaj pełnią one służbę łącznościowców, medyków, psychologów, logistyków, informatyków itd., jeśli zaś obejmują stanowisko dowódcy, to dotyczy to przede wszystkim plutonu lub małych zespołów ${ }^{14}$. W odniesieniu do misji zagranicznych liczba kobiet wzrosła - w misji w Afganistanie udział wzięło 59 pań ${ }^{15}$.

W Polsce kobiety pełniły również funkcje rzeczników prasowych, ponieważ ich odbiór jest korzystniejszy i tworzą one pozy-

\footnotetext{
11 Dane statystyczne pochodza z 31 grudnia 2016 r. Bardziej aktualne dane nie zostały opublikowane przez Ministerstwo Obrony Narodowej (Ministerstwo Obrony Narodowej, Wojskowa służba kobiet [Dostęp: 28.01.2017]. Dostępny w World Wide Web: <http://bip.mon.gov.pl>).

12 E. Posel-Częścik, Kobiety w siłach zbrojnych państw NATO, „Biuletyn PISM” 2001, nr 29, s. 361-368.

13 M. Palczewska, B. Drapikowska, Stużba wojskowa kobiet wyzwaniem dla Sit Zbrojnych RP, „Obronność. Zeszyty Naukowe” 2014, nr 3, s. 106-107; Ministerstwo Obrony Narodowej, Wojskowa służba kobiet [Dostęp: 28.01.2017]. Dostępny w World Wide Web: <http://bip.mon.gov.pl>.

14 A. Giddens, Socjologia, tłum. A. Szulżycka, Warszawa 2007, s. 729.

15 Rzecznikiem Ministerstwa Obrony Narodowej jest mjr Anna Pęzioł-Wójtowicz.
} 
tywny obraz instytucji. $Z$ analizy pt. Stużba zawodowa kobiet żotnierzy, przeprowadzonej przez Wojskowe Biuro Badań Społecznych w 2009 r., wynika, że ponad 84\% kobiet jest zadowolonych $z$ pełnionych obowiązków służbowych, równocześnie podkreślając, że nie wpływa to na ich obowiazki domowe. Milena Palczewska i Barbara Drapikowska w artykule Stużba wojskowa kobiet wyzwaniem dla Sił Zbrojnych $R P$ zaprezentowały wyniki badań empirycznych. Według nich żołnierze mężczyźni coraz częściej współpracuja $z$ żołnierzami kobietami i nie widzą większych przeciwskazań do pełnienia przez nie różnych stanowisk, ale jedna trzecia badanych odpowiedziała negatywnie, powołując się na wzorce zaczerpnięte m.in. $z$ sił zbrojnych Wielkiej Brytanii, gdzie dostęp do stanowisk jest ograniczony. Zdaniem autorek negatywne nastawienie mężczyzn wynika $z$ nierówności $\mathrm{w}$ dostępie do stanowisk, wyznaczonych kryteriów sprawności fizycznej oraz $z$ zachowania względem kobiet $\mathrm{w}$ sytuacjach społecznych, np. całowania kobiety $\mathrm{w}$ dłoń ${ }^{16}$. Należy zgodzić się $z$ ekspertami, że określenie miejsca i roli kobiet w środowisku wojskowym wymaga dalszych badań.

$Z$ roku na rok kobiety obejmuja coraz wyższe stanowiska. Dziennikarze szczególnie opisywali sytuację, gdy kobieta pilotowała samolot F-16, czy gdy po raz pierwszy w historii Polskiej Marynarki Wojennej kobieta (kpt. Katarzyna Mazurek) objęła dowodzenie okrętem ORP Lublin ${ }^{17}$.

Szczególna sytuacja jest funkcjonowanie kobiet w środowisku sił specjalnych. Nie służą one w zespołach bojowych, ponieważ sa słabsze fizycznie i pewną trudność stanowiłoby ewakuowanie innego żołnierza $z$ pola walki. Żołnierze jednostek specjalnych, np. Navy Seals, podejmowali próbę stworzenia zespołu bojowego złożonego wyłącznie $z$ kobiet, wyniki jednak były negatywne ${ }^{18}$.

16 M. Palczewska, B. Drapikowska, op. cit., s. 106. Na temat studiów nad płcia szerzej w publikacji: C. Renzetti, D. Curran, Kobiety, mężczyźni i społeczeństwo, Warszawa 2008, s. 304-312.

17 Ł. Zalesiński, Okręt $w$ rękach kobiety [Dostęp: 28.01.2017]. Dostępny w World Wide Web: <http://www.polska-zbrojna.pl>.

18 Vide: NRP.org, Słaba płeć? Kobiety będa walczyć $w$ Marines $i$ Navy SEALs [Dostęp: 28.01.2017]. Dostępny w World Wide Web: <http://www.newsweek.pl>. 
Warto wskazać, że kobiety uczestniczą w elitarnych kursach i kończa je $z$ wysokimi lokatami, czego przykładem jest ukończenie przez Amerykankę kursu Rangers ${ }^{19}$.

Obecnie w Norwegii funkcjonuje jednostka specjalna „Jegertroppen"20 stworzona wyłącznie przez kobiety. Trwaja badania związane $z$ wykorzystaniem tej jednostki na polu walki, a także szansami i zagrożeniami $z$ tego wynikajacymi. W innych państwach kobiety aktywnie uczestniczą w siłach zbrojnych.

\section{Służba kobiet w siłach zbrojnych na przykładzie wybranych państw}

Rozważając służbę kobiet w siłach zbrojnych, należy wyróżnić państwa, które w istotny sposób wywierały wpływ na kształtowanie obrazu kobiet w armii. Można do nich zaliczyć Stany Zjednoczone Ameryki, Zjednoczone Królestwo Wielkiej Brytanii i Izrael. Oczywiście różnorodność służby wynika z uwarunkowań politycznych i kulturowych.

Prezydent Stanów Zjednoczonych Ameryki Bill Clinton dążył do stworzenia oddziałów złożonych zarówno z kobiet, jak i mężczyzn bez względu na wyznawana religię czy poglądy. Ten zamiar stworzenia wielowymiarowej armii odzwierciedlał strukturę społeczną ówczesnego państwa. Jednym $z$ podnoszonych argumentów przeciwko udziałowi kobiet żołnierzy była kwestia rozpraszania uwagi mężczyzn na polu walki, a w konsekwencji obniżenie ich zdolności bojowej21.

$Z$ czasem kobiety na trwałe wpisały się w obraz amerykańskiej armii. Uczestniczyły w misjach w Iraku i Afganistanie. Pełniły służbę patrolową, medyczna, a także ochraniały afgańskie ko-

19 H. Yan, B. Starr, E. Scott, 2 women will graduate from Army Ranger course [Dostęp: 28.01.2017]. Dostępny w World Wide Web: <http://edition.cnn.com>.

20 A. Blicharz, Jegertroppen - jednostka sił specjalnych złożona wyłacznie $z$ kobiet [Dostęp: 28.01.2017]. Dostępny w World Wide Web: <http://www.nowastrategia. org.pl>.

21 USA: Bez ograniczeń dla kobiet $w$ armii [Dostęp: 28.01.2017]. Dostępny w World Wide Web: <http://www.defence24.pl>. 
biety podczas walk. Za bezpośrednią walkę $z$ wrogiem zostały odznaczone odznaka bojowa. Momentem przełomowym było ogłoszenie przez Sekretarza Obrony Stanów Zjednoczonych Ameryki Ashton Carter, że wszystkie stanowiska będą dostępne także dla kobiet22.

Równouprawnienie jest niezwykle ważne w amerykańskiej armii, gdzie szczególnie zwraca się uwagę na przejawy dyskryminacji ze względu na płeć. Dopuszczenie kobiet wiązało się przede wszystkim ze spełnieniem wymagań odpowiednich dla danego stanowiska ${ }^{23}$. Należy zauważyć, że płeć nie powinna być czynnikiem determinujacym przydzielenie danej osoby do stanowiska, ponieważ, odmawiając dostępu do danej funkcji, w taki sam sposób można dyskryminować zarówno kobiety, jak i mężczyzn. Przyjęcie określonych kryteriów i dobór kandydata spełniającego optymalne warunki powinny warunkować jego zatrudnienie.

Podobna otwartość na obecność kobiet w strukturze sił zbrojnych przejawia środowisko wojskowe Wielkiej Brytanii. Szacuje się, że kobiety stanowia $10 \%$ całości armii, nie sa jednak dopuszczane do służby w Royal Marines oraz w batalionach piechoty. Oznacza to, że nie walczą bezpośrednio $z$ wrogiem na polu walki. Argumentami przeciwko służbie kobiet w tego rodzaju formacjach były ich ograniczenia fizyczne, w tym podatność na zranienia.

Przedstawiciele Ministerstwa Obrony Narodowej Wielkiej Brytanii wyrażali opinię, że relacje tworzące się pomiędzy kobietami i mężczyznami moga obniżać morale żołnierzy. Pomimo licznych wattpliwości co do efektywności i słuszności służby kobiet w siłach zbrojnych doceniono ich działalność podczas misji zagranicznych ${ }^{24}$. Choć nie walczyły bezpośrednio, to budowały pozy-

22 P. Milewski, Panie Marines ida na front [Dostęp: 28.01.2017]. Dostępny w World Wide Web: <http://www.newsweek.pl>.

23 Vide: A. Ludwiczyński, Alokacja zasobów ludzkich organizacji [w:] Zarzadzanie zasobami ludzkimi. Tworzenie kapitału ludzkiego organizacji, red. H. Król, A. Ludwiczyński, Warszawa 2006, s. 211.

24 A. Komosa, Obecność kobiet $w$ armii obniża morale żotnierzy? Wielka Brytania chce wysłać panie na pierwsza linie frontu [Dostęp: 28.01.2017]. Dostępny w World Wide Web: <http://natemat.pl>; M. Giannangeli, Former British Army 
tywne relacje $z$ przedstawicielami miejscowej ludności, w tym $z$ kobietami żyjacymi w danym regionie. Służba kobiet na terenach objętych wojna miała także wymiar psychologiczny. Przykładem jest sytuacja, gdy w 2010 r. kobieta żołnierz będąca medykiem, realizując swoje zadania, zneutralizowała bojownika25.

Kobiety pełnią też służbę na stanowiskach pielęgniarek, logistyków, koordynatorów nalotów, a także w tych zawodach, które jak podkreśliła psycholog Wilhelmina Wosińska - sa uznawane za typowo męskie, np. mechaników ${ }^{26}$. Warto zauważyć, że spoty reklamowe Sił Zbrojnych Zjednoczonego Królestwa Wielkiej Brytanii i Irlandii Północnej, prezentujace służbę żołnierzy i zachęcające do wstapienia w ich szeregi, były profilowane w zależności od płci. Ta sama historia zawarta w spocie była przedstawiana zarówno $z$ perspektywy mężczyzny, jak i kobiety.

Inaczej wygląda służba kobiet w państwach, w których jest ona obowiąkowa. W Izraelu kobiety, podobnie jak mężczyźni, odbywają obowiązkową służbę wojskową, która trwa dwa lata. Wynika to $z$ sytuacji geopolitycznej Izraela, ale częściej podkreślanym argumentem sa pobudki patriotyczne młodzieży. Pomimo że służbę wojskową odbywa się niezależnie od płci, różnice pojawiają się już na poziomie szkolenia oraz dostępnej broni27.

W artykule Kobiety $w$ Izraelskich Siłach Obronnych Przemysław Majka opisał czynniki uniemożliwiające służbę kobiet w armii, takie jak testy psychologiczne, zły stan zdrowia czy brak odpowiedniego wykształcenia przynajmniej na poziomie podstawowym. Interesujaca inicjatywa prospołeczną, kształtująca pozytywny obraz izraelskiej armii, jest cykl wykładów w szkołach, które dotycza nie tylko sił zbrojnych, ale omawia się np. kwestie

chief warns recruiting women to front-line roles [Dostęp: 28.01.2017]. Dostępny w World Wide Web: <http://www.express.co.uk>.

25 Ibidem; vide: T. Ross, British Army's women soldiers to go into combat [Dostęp: 28.01.2017]. Dostępny w World Wide Web: <http://www.telegraph. co.uk>.

26 W. Wosińska, op. cit., s. 355.

27 A. Mitraszewska, Równość płci $w$ izraelskiej armii [Dostęp: 28.01.2017]. Dostępny w World Wide Web: <http://www.wysokieobcasy.pl>; vide: L. Abramson, Women In Combat: Some Lessons From Israel's Military [Dostęp: 28.01.2017] Dostępny w World Wide Web: <http://www.npr.org>. 
obyczajowe. Podkreśla się, że wojsko może pomóc spełnić pasje, przeżyć przygodę, gwarantuje też stabilność zatrudnienia.

Kobiety, które zdecyduja się na pracę $\mathrm{w}$ armii, wykonują głównie obowiąki administracyjne (np. w dziale prawnym) oraz pracuja jako instruktorzy. Jednocześnie nie podejmuje się tematu wyznaczania kobiet na mniej prestiżowe stanowiska i ograniczonych możliwości awansu. Przeciwnicy kobiet w izraelskiej armii podkreślaja nie tylko kwestie związane $z$ płcią i ich zdolnościami do realizacji określonych zadań, lecz przede wszystkim ze zdolnością bojową sił zbrojnych 28 .

Inne poglądy dotyczace służby kobiet wyrażali przedstawiciele Sił Zbrojnych Federacji Rosyjskiej, gdzie wojsko zarezerwowane było jedynie dla mężczyzn. Opinię tę potwierdziła także pierwsza kobieta generał w Federacji Rosyjskiej Jelena Kniaziewa, która podkreśliła, że wojna to męska rzecz ${ }^{29}$. Pomimo przedstawiania takiego stanowiska przez rosyjskich wojskowych Prezydent Federacji Rosyjskiej Władimir Putin wyznaczył na prokuratora generalnego Krymu Natalię Pokłonskają. W ten sposób docenił jej bezkompromisowość w tłumieniu buntu na Krymie i ugruntował swój pozytywny wizerunek wśród ludności popierającej agresję na Ukrainę.

\section{Wnioski}

$Z$ roku na rok wzrasta liczba kobiet podejmujących służbę wojskowa. W przyszłości tendencja ta zostanie utrzymana, a kobiety będa obejmować kluczowe stanowiska w siłach zbrojnych. $Z$ czasem obecny stan rzeczy może stać się jedynie historia, a to,

\footnotetext{
28 P. Majka, Kobiety $w$ Izraelskich Siłach Obronnych [Dostęp: 28.01.2017]. Dostępny w World Wide Web: <http://www.almaszrik.uni.lodz.pl>.

29 M. Dura, Płeć piękna $w$ armii? Tak, ale tylko $u$ wybranych [Dostęp: 28.01.2017]. Dostępny w World Wide Web: <http://www.defence24.pl>; vide: B. Renz, H. Smith, Russia and Hybrid Warfare - going beyond the Label [Dostep: 28.01.2017]. Dostępny w World Wide Web: <http://www.helsinki.fi>; K. Geers, Cyberwar in perspective: Russian Aggression against Ukraine, Tallinn 2015, passim.
} 
co dzisiaj wydaje się nierealne i poza zasięgiem kobiet, może stać się standardem w siłach zbrojnych.

W związku $z$ rozwojem nowego rodzaju sił zbrojnych - wojsk obrony terytorialnej - kobiety uzyskaja łatwiejszy dostęp do służby w regionie, w którym zamieszkują. Dotychczas czynnikiem ograniczającym możliwość ich służby była trudność pogodzenia obowiązków służbowych $z$ rolą żony i matki. Terytorialna służba wojskowa umożliwia pełnienie jej w środowisku lokalnym, bez ponoszenia szkód w życiu zawodowym i prywatnym. Kobiety w jeszcze większym stopniu będa miały możliwość samorealizacji i sprawdzenia się w roli żołnierza.

Pomimo zmiany paradygmatu roli kobiety w siłach zbrojnych wciąż pojawiają się następujące problemy:

- przełamanie stereotypowego myślenia o kobietach w siłach zbrojnych,

- pełnienie służby w środowisku zdominowanym przez mężczyzn,

- pogodzenie obowiązków rodzinnych z praca zawodowa,

- narażenie w większym stopniu na patologie społeczne, np. mobbing,

- brak możliwości szybkiego awansu oraz realizacji swoich aspiracji zawodowych.

Niewątpliwie służba kobiet w siłach zbrojnych wymaga edukacji społeczeństwa i prezentowania pozytywnych walorów aktywizacji kobiet w środowisku wojskowym, które zmieniaja otaczajacca rzeczywistość. Należy zwrócić uwagę, że kształtowanie obrazu sił zbrojnych jako miejsca otwartego na potrzeby kobiet, czyni $z$ nich godnego zaufania partnera społecznego. Wykorzystanie cech psychofizycznych oraz umiejętności przypisanych kobietom zwiększy potencjał armii na polu walki. Warto nadmienić, że w przyszłości zwycięstwo coraz częściej będzie w większym stopniu uzależnione od umiejętności zdobywania „serc i umysłów” ludzi niż prowadzonych działań zbrojnych. 


\section{Podsumowanie}

Służba kobiet stanowi wyzwanie dla sił zbrojnych. Pomimo ich obecności $\mathrm{w}$ środowisku wojskowym nadal wiele kwestii wymaga poszukiwania optymalnych rozwiązań. W ciagu ostatniej dekady część stereotypów związanych ze służbą kobiet w wojsku została zniwelowana. Obecnie kobiety coraz częściej zajmuja wyższe stanowiska bądź też obejmuja te, które dotychczas były zarezerwowane jedynie dla mężczyzn. Oprócz tego rozwój technologii i walka $z$ przeciwnikiem nie tylko na danym terytorium, lecz także np. w cyberprzestrzeni powoduja, że bierze się pod uwage predyspozycje kobiet do służby w siłach zbrojnych.

Analizując sytuację kobiet $\mathrm{w}$ armiach różnych państw, warto zauważyć, że większość problemów, z którymi stykaja się one same, jak również ich przełożeni jest bardzo podobnych. W zależności od stopnia zaawansowania i otwartości sił zbrojnych rozwiązania tych problemów szuka się, prowadząc np. badania empiryczne. Służba kobiet $\mathrm{w}$ siłach zbrojnych, niezależnie od państwa, wymaga odwagi, poświęcenia, przezwyciężenia stereotypów, aby efektywnie wypełniać obowiązki związane $z$ obroną ojczyzny.

\section{Bibliografia}

\section{Opracowania}

Aronson Elliot, Człowiek istota społeczna, przeł. Józef Radzicki, Warszawa: PWN, 2009, ISBN 978-83-01-14497-5.

Cialdini Robert B., Kenrick Douglas T., Neuberg Steven L., Psychologia społeczna, przeł. Agnieszka Nowak, Gdańsk: Wyd. Gdańskie, 2006, ISBN 83-87957-62-3.

Czaja Jan, Kulturowe czynniki bezpieczeństwa, Kraków: AFM, 2008, ISBN 978-83-7571-000-7.

Drapikowska Barbara, Kompetencje dowódcze kobiet - żolnierzy [w:] Zarzadzanie $i$ dowodzenie we współczesnych uwarunkowaniach, red. Marek Chmielecki, Magdalena El Ghmari, Warszawa: AON, 2012. 
25 lat wojskowej służby kobiet, red. Bożena Szubińska, Agnieszka Szczygielska, Dorota Kurek, Warszawa: AON, 2015, ISBN 978-837523-386-5.

Hann Chris, Antropologia społeczna, przeł. Sebastian Szymański, Kraków: Wydawnictwo Naukowe Uniwersytetu Jagiellońskiego, 2008, ISBN 978-83-233-2573-4.

Haring Ellen L., What Women Bring to the Fight, „Parameters” 2013, Vol. 43, No. 2.

Hołyst Brunon, Bezpieczeństwo gatunku ludzkiego, Warszawa: PWN, 2016, ISBN 978-83-01-18427-8.

Geers Kenneth, Cyberwar in perspective: Russian Aggression against Ukraine, Tallinn: CCDCOE, 2015, ISBN 978-1-60750-060-5.

Giddens Anthony, Socjologia, przeł. Alina Szulżycka, Warszawa: PWN, 2007, ISBN 978-83-01-16956-5.

Lewellen Ted C., Antropologia polityczna, przeł. Alicja Dąbrowska, Tomasz Sieczkowski, Santa Barbara 2003, ISBN 978-83-233-3030-1.

Ludwiczyński Antoni, Alokacja zasobów ludzkich organizacji [w:] Zarzadzanie zasobami ludzkimi. Tworzenie kapitału ludzkiego organizacji, red. Henryk Król, Antoni Ludwiczyński, Warszawa 2006.

Palczewska Milena, Drapikowska Barbara, Służba wojskowa kobiet wyzwaniem dla Sił Zbrojnych RP, „Obronność. Zeszyty Naukowe” 2014, nr 3, ISSN 2299-2316.

Posel-Częścik Edyta, Kobiety w siłach zbrojnych państw NATO, „Biuletyn PISM" 2001, nr 29.

Rokicki Bronisław, Stres [w:] Psychospołeczne uwarunkowania zachowań jednostek i grup społecznych $w$ sytuacji zagrożen. Wybrane problemy, red. Krzysztof Loranty, Warszawa: AON, 2010.

Renzetti Claire, Curran Daniel, Kobiety, mężczyźni i społeczeństwo, Warszawa: PWN, 2008, ISBN 978-83-01-14570-5.

Służba Polek na frontach II wojny światowej. Materiały sesji popularnonaukowej $w$ Toruniu $w$ dniach 16-17 listopada 1996 roku. Cz. 2. Referaty $i$ komunikaty, red. Elżbieta Zawacka, Toruń: Fund. Archiwum Pomorskie Armii Krajowej, 1998.

Wojciszke Bogdan, Człowiek wśród ludzi. Zarys psychologii społecznej, Warszawa: Wydawnictwo Naukowe Scholar, 2006, ISBN 978-837383-181-0.

Wosińska Wilhelmina, Psychologia życia społecznego, Gdańsk: Gdańskie Wydawnictwo Psychologiczne, 2004, ISBN 83-89574-34-9. 
Zarzadzanie i dowodzenie we współczesnych uwarunkowaniach, red. Marek Chmielecki, Magdalena El Ghmari, Warszawa: AON, 2012, ISBN 978-83-7523-188-5.

Zarzadzanie zasobami ludzkimi. Tworzenie kapitału ludzkiego organizacji, red. Henryk Król, Antoni Ludwiczyński, Warszawa: PWN, 2006, ISBN 978-83-01-14887-4.

\section{Zasoby internetowe}

Abramson Larry, Women In Combat: Some Lessons From Israel's Military [Dostęp: 28.01.2017]. Dostępny w World Wide Web: <http://www. npr.org>.

Blicharz Adrian, Jegertroppen - jednostka sił specjalnych złożona wyłacznie z kobiet [Dostęp: 28.01.2017]. Dostępny w World Wide Web: $<$ http:/ /www.nowastrategia.org.pl>.

Dura Maksymilian, Płeć piękna $w$ armii? Tak, ale tylko $u$ wybranych [Dostęp: 28.01.2017]. Dostępny w World Wide Web: <http://www. defence24.pl>.

Elżbieta Zawacka: byłam jedyna Cichociemna [Dostęp: 10.01.2017]. Dostępny w World Wide Web: <http://www.polskieradio.pl>.

Giannangeli Marco, Former British Army chief warns recruiting women to front-line roles [Dostęp: 28.01.2017]. Dostępny w World Wide Web: <http://www.express.co.uk>.

JM, Armia celuje $w$ kobiety. Chce mieć ich więcej $w$ swoich szeregach [Dostęp: 10.01.2017]. Dostępny w World Wide Web: <http://www. pulshr.pl>.

Komosa Agata, Obecność kobiet w armii obniża morale żotnierzy? Wielka Brytania chce wysłać panie na pierwsza linię frontu [Dostęp: 28.01.2017]. Dostępny w World Wide Web: <http://natemat.pl>.

Majka Przemysław, Kobiety w Izraelskich Siłach Obronnych [Dostęp: 28.01.2017]. Dostępny w World Wide Web: <http://www.almaszrik. uni.lodz.pl>.

Milewski Piotr, Panie Marines ida na front [Dostęp: 28.01.2017]. Dostępny w World Wide Web: <http://www.newsweek.pl>.

Ministerstwo Obrony Narodowej, Przewodniczaca Rady ds. Kobiet $w S Z$ $R P$ [Dostęp: 10.01.2017]. Dostępny w World Wide Web: <http:mon. gov.pl/pl>.

Ministerstwo Obrony Narodowej, Wojskowa służba kobiet [Dostęp: 28.01.2017]. Dostępny w World Wide Web: <http://bip.mon.gov.pl>. 
Mitraszewska Agnieszka, Równość płci w izraelskiej armii [Dostęp: 28.01.2017]. Dostępny w World Wide Web: <http://www.wysokie obcasy.pl>.

MM/PAP, Zabić kata [Dostęp: 28.01.2017]. Dostępny w World Wide Web: <www.newsweek.pl>.

NRP.org, Słaba płeć? Kobiety będa walczyć $w$ Marines i Navy SEALs [Dostęp: 28.01.2017]. Dostępny w World Wide Web: <http://www. newsweek.pl>.

Renz Bettina, Smith Hanna, Russia and Hybrid Warfare - going beyond the Label [Dostęp: 28.01.2017]. Dostępny w World Wide Web: $<$ http:/ /www.helsinki.fi>.

Ross Tim, British Army's women soldiers to go into combat [Dostęp: 28.01.2017]. Dostępny w World Wide Web: <http://www.telegraph. co.uk>.

Sejm RP, Odpowiedź podsekretarza stanu w Ministerstwie Obrony Narodowej - z upoważnienia ministra - na interpelacje nr $16633 \mathrm{w}$ sprawie służby zawodowej kobiet $w$ armii [Dostęp: 10.01.2017]. Dostępny w World Wide Web: <http://orka2.sejm.gov.pl>.

Swalski Jerzy, Pamięć po latach. Wspomnienia uczestników zamachu na Franza Kutschere [Dostęp: 28.01.2017]. Dostępny w World Wide Web: <http://www.polskieradio.pl>.

USA: Bez ograniczeń dla kobiet $w$ armii [Dostęp: 28.01.2017]. Dostępny w World Wide Web: <http://www.defence24.pl>.

Yan Holly, Starr Barbara, Scott Eugene, 2 women will graduate from Army Ranger course [Dostęp: 28.01.2017]. Dostępny w World Wide Web: <http://edition.cnn.com>.

Zalesiński Łukasz, Okręt $w$ rękach kobiety [Dostęp: 28.01.2017]. Dostępny w World Wide Web: <http://www.polska-zbrojna.pl>.

Zamach na Franza Kutschere [Dostęp: 10.01.2017]. Dostępny w World Wide Web: <http://www.polskieradio.pl>. 